\title{
Factors Affecting Brand Awareness
}

\author{
Bora Gündüzyeli \\ ${ }^{1 *}$ İstanbul Ayvansaray Üniversitesi, İktisadi İdari ve Sosyal Bilimler Fakültesi, Yönetim Bilişi̧m Sistemleri Bölümü, İstanbul, Türkiye, (ORCID: 0000-0001-5098- \\ 8713),boragunduzyeli@ayvansaray.edu.tr
}

(First received 30 March 2021 and in final form 8 August 2021)

(DOI: 10.31590/ejosat.906281)

ATIF/REFERENCE: Gündüzyeli, B., (2021). Factors Affecting Brand Awareness. Avrupa Bilim ve Teknoloji Dergisi, (31), 675-680.

\begin{abstract}
The rapidly changing and developing conditions since the industrial era have increased the consumers' chances of choice, and this situation has exposed organizations to a strong competition. As a result of the promotional activities carried out to promote the products and to direct the consumer to purchase, consumers are faced with too many messages.

In this context, consumers buy not only the product or service, but also the image and status of the brand, the value of the product or service they intend to purchase. In the face of this situation, institutions try to establish an emotional bond with the customer by determining the necessary strategies and in this way increase brand awareness.

One of the best ways to increase brand awareness is to expose it to as many customers as possible, and this awareness is a prerequisite for an idea and perception of the brand. This idea for the brand includes both remembering and recognition of the brand.

In the light of this information, the effects of advertising, mascot use, product placement, event marketing and social responsibility concepts, which are among the variables that affect brand loyalty, are included in this study.
\end{abstract}

Keywords: Advertising, Mascot Use, Product Placement, Event Marketing, Social Responsibility.

\section{Marka Farkındalığını Etkileyen Unsurlar}

\section{$\ddot{\text { Öz }}$}

Sanayi döneminden bu yana hızla değişen ve gelişen koşullar tüketicilerin seçim şansını artırmış bu durum örgütleri güçlü bir rekabet ile karşı karşıya bırakmıştır. Ürünlerin tanıtılması ve tüketiciyi satın almaya yöneltmek için yapılan tutundurma faaliyetleri neticesinde tüketiciler çok fazla mesaj ile karşı karşıya kalmaktadır.

Bu bağlamda tüketiciler sadece salt ürün veya hizmeti değil satın almayı düşündükleri ürün veya hizmetin katacağı değeri markanın imajını ve statüsünü de satın almaktadırlar. Bu durum karşısında kurumlar gerekli stratejiler belirleyerek müşteri ile duygusal bağ kurabilme ve bu yolla marka farkındalığını artırma çabasına girmektedirler.

Marka farkındalığını attırmanın en iyi yollarından biri olabildiğince çok müşteriye maruz bırakılmasıdır ve oluşan bu farkındalık markaya dair fikir ve algı oluşabilmesinin ön koşuludur. Markaya yönelik oluşan bu fikir markanın hem hatırlanmasını hem de tanınmasını içermektedir.

Bu bilgiler ışığında bu çalışmada marka bağlılı̆̆ına etkisi olan değiş̧enlerden reklam, maskot kullanımı, ürün yerleştirme, olay pazarlaması ve sosyal sorumluluk kavramlarının etkilerine yer verilmiştir.

Anahtar Kelimeler: Reklam, Maskot Kullanımı, Ürün Yerleştirme, Olay Pazarlaması, Sosyal Sorumluluk. 


\section{Introduction}

Being recognized and creating familiarity with people is the essence of advertising. The familiarity created must be effective and long-lasting. Familiarity should be able to create a customer loyalty to the brand. Again, familiarity should be seen as a general image-building power derived from brand identity.

Historically, awareness of a brand's advertisement has been considered one of the most important steps for effective advertising. From the advertisers' point of view, a successful marketing communication campaign should be memorable, as the opportunity to purchase the product that appears in mass media is often delayed.

Another variable that has an important impact on brand awareness is the use of mascots. The commercial actor used in the use of mascots as well as in advertising must be in accordance with the brand spirit. It is known that commercial characters appearing on product labels have the role of giving identity to the product.

Brand placement should be considered as a type of application that works for company owners, especially film owners, as they are used in films. Considering the benefits of companies, it can be seen that some messages can reach and opportunities can be seized. There are also pro-firm benefits such as increasing brand awareness, strengthening brand image, and encouraging consumers to use the brand. Of course, it can be very useful in terms of increasing the sales of the products.

Event or event marketing is referred to as experiential marketing in the literature or Event Marketing in foreign literature sources. All these concepts refer to the same subject and can be expressed as "Events" in total. The impact on the customer is important in terms of the image of the brand and the emotional bond it establishes between the brand and the customer.

When the relationship between social responsibility activities and brand awareness is examined, we come across a sense of well-being. The concept of social responsibility, which aims to meet the philanthropic needs of both individuals and institutions, increases the likelihood of the brand promoted in this way.

\section{Factors Affecting Brand Awareness}

\subsection{Brand Awareness and Advertising Relationship}

Advertising has a significant deliberate impact on brand awareness. This is necessary for sentiment advertising effects (e.g., brand liking) and behavior-related advertising effects (e.g., purchase requests) (Valkenburg \& Buijzen, 2005, p. 457). Many people state that advertisements are beneficial by potentially increasing one's satisfaction and raising awareness about products (Resnik \& Stern, 1977, p. 12).

It is observed that advertisers compete by constantly developing new forms of communication in order to attract the attention of the customers and generate desire. It is observed that the combination of informational or program-sized new message formats is called "non-traditional messages" or "hybrid messages" and these type of messages differ from traditional advertising messages. (Rodrigue, 2006, p. 32).
In a study, it was observed that liking a certain scene in an advertisement is related to being remembered. Here, a technique used to measure the effect of a loved or liked advertisement on recall is used. Accordingly, it has been shown that there is a significant positive effect between liking and remembering (Youn et al., 2001, p. 11). Subsequent studies indicate that the recall rate of advertisements with and without assistance and a higher recall is achieved when the highest level of liking is achieved in the ad. It has been observed that if there is a minimum level of liking in the advertisement, the recall is lower (www.ciadvertising.org, 11.05.2018)

Advertisers and advertising agencies prefer to convey the messages they want to convey, especially in large-budget advertising projects, to the target audience by telling the experiences of someone who has used the product or service in front of the camera. In this kind of advertising application, ordinary people are used as well as celebrities from time to time. Famous people have a realistic and interesting story about the brand, product or service in question, which can increase credibility and awareness. (Elden, 2003, p. 75).

An example of how the ad works over time is provided by Buzzell and Baker. Buzzell and Baker found that in one case, with the cut of the ad, $40 \%$ of sales were not affected in the first month after the ad budget cut, but that sales declined in the second and third months after the budget cut (Franses \& Vriens, 2004, p. 5). Changing the effects of image and brand positioning (repositioning) may take longer as a result of an advertising campaign rather than changes in brand awareness or sales. What is interesting is that competitive advertising can also create its own extra brand awareness and purchases (Odabasi \& Oyman, 2005, p. 365).

The use of famous people in advertising and promotional activities is also a very common method to create brand awareness. With the use of famous people in advertising and promotional activities, brands, slogans and lines play an important role in creating brand awareness by settling in the daily language of the society and leaving a long-term impact on consumers (Tigli, 2010, p. 82). Graeme Turner, an Australian professor who has done many research on the media and world of celebrities, states that the celebrity is actually a presentation style. According to Turner, the effect of this presentation increases with the promotion, advertisement, marketing and media industry and thus becomes a cultural format that includes social functions that are better understood by people (Turner, 2006, p.155).

Considering the celebrity usage in television commercials in general, it can be seen that the most important reason for the famous use in such productions is that famous faces are adopted by the public and that the place related to it in the society is respectable and reliable. Advertisers use the positive perspective acquired by famous faces, who have an important place in the society, to identify them with the brand, product or service. Because advertisers want to emphasize that their brands, products or services are respected, loved and admirable, reflecting that respectable, loved and admired celebrities are the supporters of their own brands. (Televizyon.reklam.com.tr/yazilar/televizyon-reklaminda-unlukullanimi/42, 25.05.2018) For this reason, the famous use of television commercials stands out as an extremely common method since the birth of television commercials. 
Television ads are very effective in creating brand awareness, but other types of advertising also have an effect on creating brand awareness. Bilboard ads can be given as an example. Most of the outdoor advertisements in daily life are called bilboards. However, contrary to popular belief, bilboards, which are perceived as an advertisement board, are only one of the outdoor advertisements. Bilboards are panels made of aluminum or fiber material in various sizes and shapes on iron legs. Its use in our country has been after the 1980s. Billboards should be easy to understand, should be presented with large visuals, messages should be short and presented in large fonts, and should be designed with the aim of extending the short duration of the encounter with the area used (Balkas, 2006, p. $68)$.

\subsection{Brand Awareness and Mascot Usage Relationship}

The effective use of the mascot concept in marketing started at the beginning of the 20th century and is still developing. In this century, the diversification of the products and the increase in competition have created the need for brands to create awareness. For this reason, manufacturers have tried ways such as using different packaging and labeling. The use of mascots has also increased in order to achieve this differentiation (Dotz \& Husain, 2003, p. 8). Many companies use mascots to create emotional bonds with consumers. These mascots can appear in shapes that include animals, plants, figures, and people. Usually, this can be personalized in some way and makes it easier for the consumer to distinguish the brand (Callcott \& Lee 1995, p. 144).

When we think of THY, Vestel, Yumos, Turkcell, Arcelik Nestle, Dalin, Milka, or Michelin the first mascots come to mind. Although all these brands are from different sectors, the common denominator they all gather is the mascots they have. The brand distinguishes one good from another, provides information to consumers about the benefits and quality of the good, and can contribute to the recall of the good. Owning the brand strategically provides a competitive advantage. A successful brand is the main resource for the future profits of the firm. Many commercial characters have the ability to give the consumer a clue about the brand, even when the brand name is not used in the advertisement. The commercial characters (panda, lion and golfettin) in the packages of Panda, Algida Max and Golf ice cream products can be shown as the most important reasons for remembering the products. Today, mascots are used in different ways and in various fields. There are mascots used in different fields such as university and college mascots, sports team mascots, computer mascots, political party mascots, municipal mascots, international events.

Although the advertisement must be suitable for the brand spirit, the commercial character must also be suitable for the spirit and personality of the brand. It is stated that commercial characters are included in the product labels and have the role of giving identity to the product during the periods when commercial characters were used in advertisements and developed (Phillips, 1996, p. 147). For example, the same commercial characters were used in many commercials of Pinar products. According to the information on the Pinar brand's own web pages, Pinar, which has a wide product portfolio, not only promotes itself as health and pleasure products, but also positions itself as the food of both the body and the soul. Bone, gut, brain and nasal puppets were also used in the advertisements of this wide product line. In this way, products can be connected to each other in the minds of the consumer and it is guaranteed that each product has the same Pinar quality. With these commercial characters, Pinar was awarded the 2007 Golden Effie award. Phillips (1996) included the findings of Strasser (1989) and stated that for many brands, the use of the same commercial character results in a collective advertisement and that each product connects each other and helps the purchase of another (Strasser, 1989 Cited by: Phillips, 1996, p. 152).

Commercial characters have a message to be conveyed to the consumer continuously through advertising campaigns and they ensure to be remembered. According to Phillips (1996), the long-term use of commercial characters has many advantages. Because the consumer has had an experience with this commercial character before and the role of the commercial character as the product identity determiner has increased. As time passes, the consumer will learn to recognize the commercial character and the brand it offers. Another advantage of using commercial character for a long time is that advertisers can build on the brand image that consumers already have in mind. Once the consumer understands the meaning of the commercial character and can associate it with the brand, the future advertisement tries to reinforce the previous connection rather than establishing a new connection. After a while, the characters used can become nostalgic and attract consumers in this way. In this study, Phillips emphasized that a desirable meaning can be transferred to the product by adding personality and cultural meaning to the product, especially based on the work of Peirce and McBride (1996) (Phillips, 1996; as cited in: Peirce \& McBride, 1999, p. 962).

Zajonc expressed the concept of exposure as "the exposure of the individual to a stimulus in a repetitive way provides sufficient environment for an increase in his attitude towards him". In other words, familiarity leads to liking (for example, a positive or pleasant effect) (Zajonc, 1968, p. 1). It is stated that constant exposure to an imaginary stimulant such as Ronald McDonald, who is a commercial character, causes the audience to develop a positive attitude towards Ronald McDonald. However, marketers often want to sell the product of the brand, not the commercial character itself, using a commercial character. The increasing interest in the character of Ronald McDonald also increases the interest in the McDonald product line supported by advertising and promotions. (Mizerski, 1995, p. 58).

Mascots are thought to be sufficient in promoting the brand because of its strong product-advertising relationship (Phillips, 1996, p. 147). Mascots help to overcome the crowd in the market place. However, mascots can have benefits as well as disadvantages. Mascots sometimes become so remarkable that they can destroy brand awareness by eliminating all other brand elements. Because the consumer only remembers the relevant mascot and establishes an emotional relationship with it. In order to avoid this disadvantage, how and how the character will be used in brand communication should be planned well (Keller, 2003, p. 596).

Mascots can appear not only visually, but also as anthems or slogans. The Black Eagle of Besiktas, the lion of Galatasaray and the canary of Fenerbahce are good examples of this. Most of the sports teams' mascots abroad are also developed on animals. In a study conducted on sports sponsorship management in England, it was stated in the meeting with the official of the sponsoring organization in football matches that the most 
accurate extension of their creativity is to buy clothes to create mascots before, during and after the matches (Chadwick \& Thwaites, 2005, p. 328).

\subsection{Brand Awareness and Product Placement Relation}

The concept of product placement is not the same as the concept of brand placement. Karrh (1998) states that there is a difference between brand and product placement, which are frequently used in films or television programs. Karrh actually emphasizes that the type of placement done here is mostly "brand placement". Because in movies, products are generally not named by their names; They are indicated by their brands. However, it is noteworthy that products appear in a film without a brand name (Vollmers, 1995, p. 1). However, in the literature, the concepts of brand placement and product placement are often used interchangeably.

Brand placement can be defined as a paid message that aims to impress the audience by placing a branded product in a planned and inconspicuous way in movies or television programs (Odabasi and Oyman, 2005, p. 377). These types of messages are paid works that aim to make the consumer not forget the brand, create a certain attitude, and affect them positively.

It is noteworthy that in films made before the 1970s, branded products were used and the brand owner firm, which supported it, placed their branded products in the film by paying a certain price (Balasubramanian, 1994, p. 29). In the 1980 s, advertisers who saw that product placement was a new form of persuasive message in their advertising strategy tried to position their products in a privileged way by placing their products in the film by paying a certain amount. For example, in "Cute creature E.T", a product placement trial is made with E.T eating Reese's Pieces candy in the movie, and an incredible $65 \%$ increase in sugar sales is observed over three months. (Rodrigue, 2006 , p. 36). It was observed that there were more than 30 brand placement companies in 1986 and these companies aimed to include the brand on the stage they deemed appropriate by reading the scenario. When we look at the movies made in 1991, it is noteworthy that there were twenty-five films in total and 291 product placement works were encountered in these films and when the average was examined, 12 product placement studies were carried out per each film ( http://www.academia.edu/3857509/Product_placement, 11.09.2018).

The differences between television programs and product placement strategies in films in terms of effect were also examined experimentally. Gupta \& Lord (1998) investigated the impact of 'fame' in installation (in a prominent or inconspicuous form) and forms of presentation (verbal only, visual only, or both visual and verbal). Accordingly, in a product placement, a product can appear in a certain scene with high visibility or stand out in a scene by showing it as a part of a certain event in that event. It can also be said that with a striking product placement, the characteristic feature of the brand is not noticeable. Only in verbal product placement is some things said about the brand. In the only visual product placement type, the product or brand is shown in a certain scene. In both visual and verbal product installations, both visual and verbal elements related to the brand are combined. Experts have shown that a good recall rate is achieved after product placements (Rodrigue, 2006, 37).

It is observed that there are two different types of product placement in mass media: (http://ciadvertising.org, 2006, 11.05.2019)

1- Strategic using of brands: the use of the brand by producers, actors and directors to make a certain impact on the viewer or listener. (For example, when the actor uses the product more physically and attracts the product.)

2- Using brands as a promotional tool: With this, it is possible for those who advertise to the program or film owner to pay a certain price or make barter agreements or do this free.

With the developments in the product placement industry, it is observed that these two forms are fused in order to create a more realistic image in the films, and at the same time, the product is offered the opportunity to be preferred.

In the product placement studies until today, Gupta and Lord (1998) examined the product placement studies by comparing them with the advertisement; Weaver and Loiver (2000) expanded their research on product placement by adding the concept of "reputation/fame" and examined product placement and advertising in a comedy program on television; it was observed that Russell (2002) expanded the product placement studies and examined the relationship between form and scenario (Rodrigue, 2006, p. 36).

From a formal point of view, it is remarkable that Gupta and Lord put forward three models as product placement strategy. These (www.ciadvertising.org, 11.05.2018);

- Only visual product placement (a product only appears on the scene),

- Audio-only product placement (the product is not shown here, only something is said about it)

- Audio and visual product placement (here the product is visible on the stage and something is said about it)

Another factor that affects viewers' remembrance of the brand or product is related to the "prominent display of the brand". Here, the brand appears in the film in a striking and impressive form. It is worth noting that the brand or elements that promote the brand have high visibility, taking place at the center of the event or in a large size, or power is noticeable when the brand cannot be displayed in a striking way (www.ciadvertising.org, 11.05.2018).

Accordingly, although product placement in films is not a common method used to increase awareness, it has been observed that it achieves very good scores in awareness measurement. The awareness scores were just below the product placement on television, outdoor media and traditional television use. The results of the study are shown in Table 1 . 
Table 1. Mara Noticeability According to the Advertised Area

\begin{tabular}{l|l|l|l|l|l|l}
\hline \multicolumn{1}{|c|}{ İdividuals \% } & $\begin{array}{l}\text { Product placement } \\
\text { in movies }\end{array}$ & $\begin{array}{l}\text { Product placement } \\
\text { on TV }\end{array}$ & $\begin{array}{l}\text { Advertising on } \\
\text { TV }\end{array}$ & $\begin{array}{l}\text { Outdoor } \\
\text { Advertising }\end{array}$ & Test Messages & Radio ads \\
\hline Adults & 47 & 52 & 61 & 53 & 19 & 40 \\
\hline Children & 61 & 62 & 71 & 60 & 23 & 47 \\
\hline
\end{tabular}

Source: http://www.academia.edu/3857509/Urun_yerlestirme 11.09.2018.

Again, in the case of advertising plus product placement studies of another research study conducted in the United States, the awareness created by the product or brand is 7 out of 10 ; being reminded is 7.5 out of 10 ; It was noted that the awareness provided by advertising only without placing a product varies between 5 and 6 out of 10 (Ertas, 2003, p. 28).

Another point that takes attention in the study is that standard product placement practices do not attract the attention of consumers in countries with high advertising pollution, such as the United States and the UK. According to the findings obtained from the research, it is concluded that $29 \%$ of the interviewees stated that the product placements made on the films may cause them to try a product, and this rate exceeds $40 \%$ in the 15-24 age group worldwide (http://www.academia.edu/3857509/Urun_yerlestirme, 11.09.2018).

Although the awareness rates are higher than expected, it is seen that there are still those who are not easily convinced. The rate of those who stated that they deliberately ignore the brands that use the product placement method was $52 \%$; it has been observed that $32 \%$ of people find such advertisements disturbing. In this analysis, it is noteworthy that those who reject are over the age of 55 (Mediacat, 2004, p.37).

Again, in the case of advertising plus product placement studies of another research study conducted in the United States, the awareness created by the product or brand is 7 out of 10 ; being reminded is 7.5 out of 10; It was noted that the awareness provided by advertising only without placing a product varies between 5 and 6 out of 10 (Ertas, 2003, p. 28). Another point that takes attention in the study is that standard product placement practices do not attract the attention of consumers in countries with high advertising pollution, such as the United States and the UK. According to the findings obtained from the research, it is concluded that $29 \%$ of the interviewees stated that the product placements made on the films may cause them to try a product, and this rate exceeds $40 \%$ in the $15-24$ age group worldwide

(http://www.academia.edu/3857509/Urun_yerlestirme 11.09.2018).

\subsection{Brand Awareness and Event Marketing Relationship}

Activity Marketing can also be defined as Experimental Marketing or Event Marketing with other definitions. All of these concepts point to the same issue. It is possible to express these concepts as "Activity". Events; plays an important role on the target audience and/or potential target groups that companies, institutions, organizations and authorities want to reach. Within each action (activity), the participants gain many benefits such as emotional benefit, sociality, interesting experiences that can meet their needs. There are many types of events, but the study has been evaluated in five subcategories (Sneath et., 2005, p. 375):
1. Sporting events (Professional or amateur)

2. Music and Entertainment

3. Festivals and Fairs

4. Social Responsibility Studies (Hospital, Health Research, Environmental Protection Activities)

5. Art and Culture (Theater, Opera, Art Gallery)

Event marketing has a positive effect on the effect of the target group, the familiarity of the customer with the brand, the image the brand leaves on the target group, the behavior of the target group with the brand, and the emotional connection that the target group establishes with the brand. In this respect, event marketing stands out compared to classical marketing communication as it encourages and enables the participation of the target group to the event (Wohlfeil \& Whelan, 2006, p. 645).

\subsection{Brand Awareness and Social Responsibility Relationship}

There is strong statistical evidence to show that consumers are indeed rising to the top of Maslow's hierarchy of needs. At the same time, the trust in traditional institutions, the main pillars of society, such as the church, the state, and the police, to which people are accustomed to belong or many acquire the concepts of social orientation and moral authority; it has declined worryingly, so a number of factors have come together to pose a threat to brands and provide an opportunity. On the other hand, social responsibility activities can be considered as a way to meet the needs of individuals and institutions for the sense of benevolence (Thompson et al., 2006, p. 52). The brand promoted in connection with an event is very likely to be remembered and recognized. Or it may be easier for a wellknown brand to increase its awareness. For example, with the social responsibility campaign of Avon brand against breast cancer, it was able to make its name heard much more easily and effectively (Keller, 2003, p. 255).

\section{Result}

The way to create brand awareness is to expose the brand to as many customers as possible, and awareness is a prerequisite for creating an idea and perception about the brand (Gwinner, 1997, p. 145). The concept of brand awareness includes the recognition and remembering of the brand and can be expressed as the power of permission in the consumer's memory (Uztug, 2003, p. 29).

It is also important how the impact of advertising spreads over various criteria (such as awareness, thinking, and purchasing) over time. It is generally accepted that the effect of a particular advertisement will continue not only in the week it is published but also in the next week, and its effect will gradually decrease in the following weeks. This decrease may be due to the memory of the viewers, as well as the consumption of the advertisement being displayed in a very short time. There are three ways that mascots communicate with consumers. These are, respectively, providing an identity to the product, promoting brand personality and ensuring continuity of promotion. Many 
studies on this topic have shown that there is a very strong link between mascots and products.

The concept of brand placement is also known as product placement, but while placing an ordinary product in that film or elsewhere does not make a difference, the preference or even the pronunciation of a branded beverage as a beverage is made directly in a planned manner and for promotion.

When looking at the studies in the literature regarding product placement strategies and its effects on recall, it was recorded how many times the brand appeared on the screen in visual product placements and from what angle the camera took the brand, and how this product or brand had an effect on the perception and recall of the consumers. In verbal product placements, it was stated that criteria such as the number of times the product or brand was mentioned in the dialogues, how the product or brand was passed during the speech, the degree of connection with the scene or event, the current tone of voice and emphasis could be effective in remembering the product or brand. In both visual and verbal installation, the product or brand is both mentioned and used, at this point, it has been determined that the actor who uses and mentions the product or brand has a certain effect on recall.

Event marketing positively affects people's familiarity with the brand, the brand image, and the behavioral and emotional bonds people establish with the brand. In this context, event marketing provides the encouragement and participation of the target audience in terms of classical marketing communication.

\section{References}

Balasubramanian, Siva K., (1994). Beyond Advertising and Publicity: Hybrid Messages and Public Policy Issues. Journal Of Advertising, 23.2, 29-46.

Balkas, E.E. (2006), Which One Is More Important In Advertising? Creativity or Ethics in Designs? With Case Study, Istanbul Ticaret Universitesi Sosyal Bilimler Dergisi, 5(9), 67-80.

Callcott, M. F., \& Lee, W. N. (1995). Establishing the spokescharacter in academic inquiry: historical overview and framework for definition. ACR North American Advances.

Chadwick, S., \& Thwaites, D. (2005). Managing sport sponsorship programs: Lessons from a critical assessment of English soccer. Journal of Advertising Research, 45(3), 328338.

Dotz, W., \& Husain, M. (2003). Meet mr. product: The art of the advertising character. Chronicle Books.

Elden, M. (2003). Reklam Yazarligi, Istanbul: Iletisim Yayinlari.

Ertas, A. (2003). Urun Yerlestirme İcin Yeni Bir Rol. Mediacat Dergisi. 11.(98), 26.

Franses, P., \& Vriens, M. (2004). Advertising effects on awareness, consideration and brand choice using tracking data. Erim Report Series Research In Management

Gupta, P. B., \& Lord, K. R. (1998). Product placement in movies: The effect of prominence and mode on audience recall. Journal of Current Issues \& Research in Advertising, 20(1), 47-59.

Gwinner, K. (1997). A model of image creation and image transfer in event sponsorship. International marketing review.14(3), 145-158,

Karrh, J. A. (1998). Brand placement: A review. Journal of Current Issues \& Research in Advertising, 20(2), 31-49.
Keller, K. L. (2003). Brand synthesis: The multidimensionality of brand knowledge. Journal of consumer research, 29(4), 595-600.

Mediacat Dergisi, (Subat 2004). Urun Yerlestirmeye Global Bir Yaklasim, 12.109:36-37. https:/www.nadirkitap.com/mediacat-dergisi-subat-2004sayi-109-krallarla-iletisimin-incelikleri-dergi24146686.html

Mizerski, R., (1995). The Relationship between Cartoon Trade Character Recognition and Attitude Toward Product Category in Young Children, Journal of Marketing, 59, 5870.

Odabasi, Y. ve Oyman, M. (2005), Pazarlama İletisimi Yonetimi, MediaCat Kitapları.

Peirce, K., \& McBride, M. (1999). Aunt Jemima isn't keeping up with the Energizer bunny: Stereotyping of animated spokescharacters in advertising. Sex roles, 40(11-12), 959968.

Phillips, B. J. (1996). Defining trade characters and their role in American popular culture. The Journal of Popular Culture, 29(4), 143-158.

Resnik, A., \& Stern, B. L. (1977). Children's television advertising and brand choice: A laboratory experiment. Journal of Advertising, 6(3), 11-17.

Rodrigue, C. S. (2006). The Impact of Masking of Persuasive Intent On Persuasive Message Effectiveness. Unpublished doctoral dissertation, Business Administration (Marketing). Unpublished doctoral dissertation,U.S.A: Lousiana State University

Sneath, J. Z., Finney, R. Z., \& Close, A. G. (2005). An IMC approach to event marketing: The effects of sponsorship and experience on customer attitudes. Journal of Advertising Research, 45(4), 373-381.

Thompson, C. J., Rindfleisch, A., \& Arsel, Z. (2006). Emotional branding and the strategic value of the doppelgänger brand image. Journal of marketing, 70(1), 50-64.

Tigli, M. (2004) Bir Aktor Olarak Markalar: Urun Yerlestirme. 1. Baski. Istanbul: Turkmen Kitabevi

Tigli, M. (2010). Pazarlama Iletisiminde Sohret Figuru, Istanbul: Beta Yayınları.

Turner, G. (2006). The mass production of celebrity: 'Celetoids', reality TV and the 'demotic turn'. International journal of cultural studies, 9(2), 153-165.

Uztug, F. (2005). Markan Kadar Konus - Marka İletisimi Stratejileri, 3. Basim Istanbul: Mediacat Kitaplar1.

Valkenburg, P. M., \& Buijzen, M. (2005). Identifying determinants of young children's brand awareness: Television, parents, and peers. Journal of Applied Developmental Psychology, 26(4), 456-468.

Vollmers , S. M.. (1995). The Impact on Children of Brand And Product Placements In Films. Unpublished doctoral dissertation, Marketing. U.S.A: The Florida State University

Wohlfeil, M., \& Whelan, S. (2006). Consumer motivations to participate in event-marketing strategies. Journal of Marketing Management, 22(5-6), 643-669.

Youn, S., Sun, T., Wells, W. D., \& Zhao, X. (2001). Commercial liking and memory: moderating effects of product categories. Journal of advertising research, 41(3), 7-13.

Zajonc, R. B. (1968). Attitudinal effects of mere exposure. Journal of personality and social psychology, 9(2p2), 1.

www.ciadvertising.org, 11.05.2018

http://www.academia.edu/3857509/Urun_yerlestirme 11.09.2018 